\title{
Coordinated radiation protection research in Europe: is it the beginning of a new era?
}

\author{
W. Rühm ${ }^{1} \cdot$ Anna A. Friedl ${ }^{2}$ A. Wojcik ${ }^{3}$
}

Received: 10 December 2017 / Accepted: 11 December 2017 / Published online: 19 December 2017

c) Springer-Verlag GmbH Germany, part of Springer Nature 2017

Recent years have seen a fundamental new development in the organisation of radiation protection research in Europe. The traditional approach has been based on determining research priorities and pursuing projects separately by each European country. International collaboration took place, but it was initiated and maintained by individual scientists. In addition, the European Commission funded collaborative projects, but research priorities were selected without direct consultation with the scientific community by a programme committee whose members were government officials and commission officers. This process was often not regarded as transparent by the scientific community. After the European Commission launched a research call on a certain topic, it also handled the evaluation of the submitted proposal and monitoring of those projects that received funding. The effect was a multitude of research activities that partly ran in parallel to each other and sometimes even lacked the capacity to solve important scientific problems.

As a new funding tool, the European Joint Programme (EJP) has been implemented for the area of radiation protection research in 2015 within the wider frame of Horizon 2020, with the launch of the CONCERT (European Joint Programme for the Integration of Radiation Protection Research) project (see http://www.concert-h2020.eu for more details). One of the basic features of CONCERT is to combine European funds from the Commission and national funds from EU member states in an effort to increase the available financial capacity of radiation protection research, adjust national research programmes, and foster synergistic

W. Rühm

werner.ruehm@helmholtz-muenchen.de

1 Institute for Radiation Protection, Helmholtz Center Munich, 85764 Neuherberg, Germany

2 Department of Radiation Oncology, University Hospital, Ludwig-Maximilians-University Munich, Munich, Germany

3 Centre for Radiation Protection Research, Stockholm University, Stockholm, Sweden effects for the benefit of radiation protection research in Europe. CONCERT organises calls and manages collaborative projects, which are selected on the basis of their compliance with research agendas that were defined by the socalled European radiation research platforms.

Currently, five such platforms exist which act as networks of research institutions committed to radiation protection research in Europe. Some of these platforms know individual membership in addition to institutional ones. The Multidisciplinary European Low-Dose Initiative (MELODI) focuses on health effects of low-dose and low-dose rate ionising radiation, with the specific aim of improving the understanding and quantification of risk (http://www.melodionline.eu) (Belli et al. 2011, 2015; Salomaa et al. 2015, 2017; Repussard 2015). The European Radiation Dosimetry Group (EURADOS) has the mission to promote research and European cooperation in the field of the dosimetry of ionising radiation. This aim is achieved by increasing the scientific understanding of dosimetry, fostering the technical development of dosimetric methods and instrumentation, and their implementation in routine dosimetry. Furthermore, EURADOS harmonizes dosimetric procedures used within the EU and their conformance with international practices (http://www.eurados.org) (Rühm and Schuhmacher 2017; Rühm et al. 2018). In the field of emergency preparedness, the mission of NERIS (European Platform on Preparedness for Nuclear and Radiological Emergency Response and Recovery) is "to establish a forum for dialogue and methodological development between all European organisations and associations taking part in decision-making of protective actions in nuclear and radiological emergencies and recovery in Europe" (http://www.eu-neris.net). The field of radiation ecology is represented by ALLIANCE (http://www.er-alliance.org) which aims at maintaining and enhancing radioecological competences and experimental infrastructures in Europe and "addresses scientific and educational challenges in assessing the impact of radioactive substances on humans and the environment". Most recently, the European Alliance 
for Medical Radiation Protection Research (EURAMED) platform was founded as an umbrella structure of several European organisations representing the medical field. It includes the European Association of Nuclear Medicine (EANM), the European Federation of Organisations of Medical Physics (EFOMP), the European Federation of Radiographer Societies (EFRS), the European Society of Radiology (ESR), and the European Society for Radiotherapy and Oncology (ESTRO). In EURAMED, these societies, for the first time, "joined forces and agreed on a collaboration to improving the application of ionising radiation in medical care by developing and exploring common research strategies and by actively promoting the translation of results into clinical practice" (http://www.eibir.org/scientific-activities/ joint-initiatives/european-alliance-for-medical-radiationprotection-research-euramed/). This group of research platforms is sometimes called MENAE.

A particular task of these platforms within CONCERT Working Package 2 is to develop strategic research agendas (SRAs) for their respective area of expertise: The aim is to define the research needs for the next decades required to improve radiation protection in Europe. In CONCERT Working Package 3 these individual SRAs of the platforms are being considered and, together with input from social sciences and humanities and also from further stakeholders, a joint SRA, joint research priorities, and-with a longterm perspective- a joint roadmap for radiation protection research in Europe is being developed. Once finished, this joint SRA and the corresponding roadmap will serve as the basis for future European calls in radiation protection research.

It is obvious that an SRA is by nature a moving target, requiring continuous update depending on the societal needs that might change and depending on the progress of science. Thus, the platforms are in a continuous process of improving their individual SRAs and publishing the results of these efforts regularly. For example, since the publication of its first SRA, MELODI has continuously improved the SRA by organising a series of annual workshops (e.g., Salomaa et al. 2013, 2015; Aerts et al. 2014). EURADOS has developed a detailed SRA on the dosimetry of ionising radiation and published the results as a EURADOS report downloadable from the EURADOS website (Rühm et al. 2014). A summary of this report was published in (Rühm et al. 2016). To improve this SRA, EURADOS organised a workshop with stakeholders in 2016 in Neuherberg, Germany. At the workshop, 23 international organisations discussed their views on the scientific needs to improve dosimetry of ionising radiation. A summary of this workshop was recently published (Rühm et al. 2017). Based on the input from this stakeholder workshop and on more recent results of funded research projects, a EURADOS Task Group of the EURADOS Council is currently working on a second version of the EURADOS SRA. NERIS has published a first version of their SRA in 2012 followed by an updated second version in 2014 . Both reports can be downloaded from the NERIS website (http://www.eu-neris.net; see also Schneider et al. 2016). ALLIANCE started the process of SRA development in 2013 (Hinton et al. 2013; STAR 2014). Since then, focus has also been set on the identification and justification of research priorities, and on the development of a roadmap in radioecology (http://www.er-alliance.eu). After its formation in 2016, EURAMED developed and published a first SRA version in 2017 (EURAMED 2017).

This issue of Radiation and Environmental Biophysics includes the most recent SRA version of MELODI (Kreuzer et al. 2017). Although a similar version of the SRA can also be found in the Internet (http://www.melodi-online.eu/), we hope that its publication in our journal will support the dissemination of the document among a broader scientific community even beyond Europe. We consider this as important, because other parts of the world may also see the need for developing programmes in radiation protection research (e.g., Dewji et al. 2017), and the SRAs developed by the European research platforms may be helpful in this process.

It is the integrating development of a joint list of research priorities and a joint roadmap within CONCERT WP3 that makes a close collaboration and interaction of the existing European platforms indispensable. Beyond CONCERT, this process has already born further fruit: typically, members of the platforms meet regularly among themselves and organise workshops, annual meetings, or other actions, to run their own business. Beyond that, however, dedicated joint actions have already been implemented. For example, end of 2013, a Memorandum of Understanding (MoU) was signed between MELODI, EURADOS, NERIS, and ALLIANCE emphasising their desire to contribute to an integrated vision of European radiation protection research. A further MoU was signed later between MELODI and EURADOS on one hand, and five European medical associations (EANM, EFOMP, EFRS, ESR, and ESTRO) to foster further collaboration among these organisations. Recently, a similar MoU was signed between MELODI, EURADOS, ALLIANCE, and NERIS on one hand, and NUGENIA (Nuclear Generation II and II Association; http://www.nugenia.org), an organisation working to advance the safe, reliable, and efficient operation of nuclear power plants. The MoU was signed in an effort to promote collaboration between the involved research platforms and associations in Europe. Furthermore, in 2016, the First European Radiation Protection Research Week (ERPW) was jointly organised by the five European platforms, in Oxford, UK (Bouffler 2017). This format was further developed, and the Second ERPW which took place this year in Paris, France, was held in conjunction with the fourth International Symposium on the Radiological Protection 
System of the International Commission on Radiological Protection (ICRP) (Clement 2018).

The above-mentioned developments demonstrate that in Europe, the scientific community active in radiation protection research has taken new responsibility-the identification of future strategic research topics and the development of roadmaps that include priority and timeline setting, as well as the draft formulation of future research calls are now upon the European researchers themselves. If the process to evaluate submitted proposals can be done in a way to avoid conflict of interest-and the procedures implemented in CONCERT prove that this is, indeed, possible, although some improvements might be envisagedthen, this development offers new chances in organisation of radiation research. This process of actively and openly involving the scientific community in a research planning and funding framework does involve some disadvantages: the danger of conflict of interest during priority setting, call text preparation as well as proposal evaluation, difficulties to integrate all relevant research organisations including university institutes in the process in a fair and equal way, an additional, significant workload for scientists that may leave less time for their own scientific work, and the allocation of financial resources from research funds to administrative processes that, in the past, were handled by European Commission officials. Nevertheless, the advantages must not be overlooked. Among those is the identification of important research topics across disciplines that will increase the overall acceptance of the issued research calls and the involved funding process, an increased legitimation and an improved efficiency of the use of tax payers' money for research, and the alignment of European research lines with national research programmes of EC member states.

In summary, we are currently experiencing a fundamentally new development in the organisation of European radiation protection research: the scientific community in radiation protection research has systematically intensified its efforts to work together across disciplines in an integrative and strategic manner, with the continuous goal of identifying, prioritising, and solving open scientific problems. We believe that in the long run, this development will improve radiation protection and contribute towards a safer use of ionising radiation. In hindsight, this might, indeed, be seen as the beginning of a new era.

\section{References}

Aerts AM, Impens NR, Baatout S, Benotmane MA, Camps J, Dabin JM, Derradji H, Grosche B, Horemans N, Jourdain JR, Moreels M, Perko T, Quintens R, Repussard J, Rühm W, Schneider T, Struelens L, Hardeman F (2014) Joint research towards a better radiation protection-highlights of the fifth MELODI workshop. $\mathrm{J}$ Radiol Prot 34:931-956
Belli M, Salomaa S, Ottolenghi A (2011) MELODI: the 'Multidisciplinary European Low-Dose Initiative'. Radiat Prot Dosim 143:330-334

Belli M, Tabocchini MA, Jourdain JR, Salomaa S, Repussard J (2015) The European initiative on low-dose risk research: from the HLEG to MELODI. Radiat Prot Dosim 166:178-181

Bouffler S (2017) Radiation Protection Week 2016, 19-23 September 2016, Oxford. J Radiol Prot 37:317-318

Clement C (2018) ICRP 2017-the fourth international symposium on the system of radiological protection. Ann ICRP 47(1S) (in press)

Dewji S, Davis J, Hertel N, Abelquist E (2017) Radiation protection research needs workshop: summary report. Oak Ridge National Laboratory, Technical report, ORNL/TM-2017/460, Oak Ridge, USA. https://doi.org/10.2172/1410925

EURAMED (2017) European Association of Nuclear Medicine (EANM); European Federation of Organizations for Medical Physics (EFOMP); European Federation of Radiographer Societies (EFRS); European Society of Radiology (ESR); European Society for Radiotherapy and Oncology (ESTRO) Common strategic research agenda for radiation protection in medicine. Insights Imaging 8:183-197

Hinton TG, Garnier-Laplace J, Vandenhove H, Dowdall M, AdamGuillermin C, Alonzo F, Barnett C, Beaugelin-Seiller K, Beresford NA, Bradshaw C, Brown J, Eyrolle F, Fevrier L, Gariel J-C, Gilbin R, Hertel-Aas T, Horemans N, Howard BJ, Ikäheimonen T, Mora JC, Oughton D, Real A, Salbu B, Simon-Cornu M, Steiner M, Sweeck L, Vives i Batlle J (2013) An invitation to contribute to a strategic research agenda in radioecology. J Environ Radioact 115:73-82

Kreuzer M, Auvinen A, Cardis E, Durante M, Harms-Ringdahl M, Jourdain JR, Madas BG, Ottolenghi A, Pazzaglia S, Prise K, Quintens R, Sabatier L, Bouffler S (2017) Multidisciplinary European Low Dose Initiative (MELODI)—strategic research agenda for low dose radiation risk research. Radiat Environ Biophys https:// doi.org/10.1007/s00411-017-0726-1

Repussard J (2015) New opportunities for European radiation protection research. J Radiol Prot 35:E5-E8

Rühm W, Schuhmacher H (2017) A success story for European Cooperation in the dosimetry of ionising radiation. Strahlenschutzpraxis $3: 36-38$

Rühm W, Fantuzzi E, Harrison R, Schuhmacher H, Vanhavere F, Alves J, Bottollier Depois JF, Fattibene P, Knežević Ž, Lopez MA, Mayer S, Miljanić S, Neumaier S, Olko P, Stadtmann H, Tanner R, Woda C (2014) EURADOS strategic research agenda: vision for dosimetry of ionizing radiation. EURADOS report 2014-01, ISSN 2226-8057, ISBN 978-3-943701-06-7, Braunschweig, Germany

Rühm W, Fantuzzi E, Harrison R, Schuhmacher H, Vanhavere F, Alves J, Bottollier Depois JF, Fattibene P, Knežević Ž, Lopez MA, Mayer S, Miljanić S, Neumaier S, Olko P, Stadtmann H, Tanner R, Woda C (2016) EURADOS strategic research agenda: vision for dosimetry of ionizing radiation. Radiat Prot Dosim 168:223-234

Rühm W, Knežević Ž, Fantuzzi E, Harrison R, Schuhmacher H, Vanhavere F, Alves J, Bottollier Depois JF, Fattibene P, Gilvin P, Lopez MA, Mayer S, Miljanić S, Olko P, Stadtmann H, Tanner R, Vargas A, Woda C (2017) Eurados Stakeholder workshop on June 30th, 2016. EURADOS report 2017-02. ISSN 2226-8057, ISBN 978-3-943701-15-9, Neuherberg, Germany

Rühm W, Bottollier-Depois JF, Gilvin P, Harrison R, Knežević Ž, Lopez MA, Tanner R, Vargas A, Woda C (2018) The work programme of EURADOS on internal and external dosimetry. Ann ICRP 47(1S) (in press)

Salomaa S, Prise KM, Atkinson MJ, Wojcik A, Auvinen A, Grosche B, Sabatier L, Jourdain JR, Salminen E, Baatout S, Kulka U, Rabus H, Blanchardon E, Averbeck D, Weiss W (2013) State of the art in research into the risk of low dose radiation exposure-findings of the fourth MELODI workshop. J Radiol Prot 33:589-603 
Salomaa S, Averbeck D, Ottolenghi A, Sabatier LSalomaa S, Averbeck D, Ottolenghi A, Sabatier L, Bouffler S, Atkinson M, Jourdain JR (2015) European low-dose radiation risk research strategy: future of research on biological effects at low doses. Radiat Prot Dosim 164:38-41

Salomaa S, Jourdain JR, Kreuzer M, Jung T, Repussard J (2017) Multidisciplinary European low dose initiative: an update of the MELODI program. Int J Radiat Biol 8:1-5

Schneider T, Lafage S, Bardelay J, Duranova T, Gallego E, Gering F, Hardeman F, Heriard-Dubreuil G, Murith C, Oughton D, Raskob
W (2016) NERIS: European platform on preparedness for nuclear and radiological emergency response and recovery: activities and perspectives. Radioprotection 51:S5-S8

STAR Consortium (2014) Strategic research agenda for radioecology - an updated version with stakeholder input. Issued on 24/02/2014, 92 p. DELIVERABLE (D-N ${ }^{\circ} 2.5$ ) Contract Number: Fission-2010-3.5.1-269672. http://www.radioecology-exchange. org/sites/www.radioecologyexchange.org/files/STAR $\% 20$ D2.5\%20Strategic\%20research\%20agenda-updated\%20version. pdf. Accessed 19 Dec 2017 